\title{
The effects of PAP therapy on energy metabolism in patients with obstructive sleep apnea syndrome
}

\author{
Ayşegül ALTINTOP \\ GEÇKIL ${ }^{1}$ \\ Özkan YETKiN ${ }^{2}$
}

Cite this article as: Altıntop Geçkil A, Yetkin Ö. The effects of PAP therapy on energy metabolism in patients with obstructive sleep apnea. Tuberk Toraks 2019;67(3):205-10.

\section{Yazıșma Adresi (Address for Correspondence)}

\section{Dr. Ayşegül ALTINTOP GEÇKIL}

Malatya Eğitim ve Araştırma Hastanesi, Göğüs Hastalıkları Kliniği, MALATYA - TÜRKIYE e-mail: aysegul.altintop@gmail.com

CCopyright 2019 by Tuberculosis and Thorax.

Available on-line at www.tuberktoraks.org.com
${ }^{1}$ Clinic of Chest Diseases, Malatya Training and Research Hospital, Malatya, Turkey

${ }^{1}$ Malatya Ĕgitim ve Araştırma Hastanesi, Göğüs Hastalıkları Kliniği, Malatya, Türkiye

${ }^{2}$ Department of Chest Diseases, Faculty of Medicine, Inonu University, Malatya, Turkey

2 Inönü Üniversitesi Tıp Fakültesi, Göğüs Hastalıkları Anabilim Dalı, Malatya, Türkiye

\section{ABSTRACT}

The effects of PAP therapy on energy metabolism in patients with obstructive sleep apnea syndrome

Introduction: In this study, changes in energy metabolism before and after treatment were compared in obstructive sleep apnea syndrome (OSAS) patients who received positive airway pressure therapy.

Materials and Methods: Thirty-nine patients (22 male, 17 female) were admitted to study. Patients for PAP therapy who had moderate to severe in polysomnography were included. Values of energy metabolism were recorded during three days via metaboic holter device, before and after PAP therapy.

Results: The mean age of the patients was $51.53 \pm 11.16$ year. In $15(38.46 \%)$ of the patients BPAP, and in $24(61.54 \%)$ of the patients CPAP treatment started. Three days after using metabolic holter device: the total daily energy consumption of the patients was found to be $482,4 \pm 296.1 \mathrm{kcal} /$ day before treatment and $524.5 \pm 343.1 \mathrm{kcal} /$ day after treatment $(p<0.0001)$; patients' daily physical activity was $7867 \pm 3319$ steps/day before treatment and $12.416 \pm 1451$ steps/day after treatment, which was considered statistically significant $(p<0001)$; the total daily resting period of the patients was $7.90 \pm$ 1.36 hours/day before treatment and $7.44 \pm 1.42$ hours/day after treatment, considered statistically significant $(p<0001)$; the total sleep duration of the patients was $5.50 \pm 1.88$ hours/day before treatment and $5.87 \pm 1.20$ hours/ day after treatment, considered statistically significant $(p<0001)$.

Conclusion: In our study, we found that daily physical activity and energy consumption increased with PAP treatment. With PAP treatment, obesity, diabetes and hypertension can be controlled. In our study, since PAP treatment was effective with effective sleep, the immobilization time was decreased and therefore the duration of daytime physical activity was 
prolonged. With these effects, patients' compliance with treatment increases. In conclusion, PAP treatment should be recommended in patients with moderate and severe OSAS.

Key words: Obstructive sleep apnea; energy metabolism; physical activity; sleep time; metabolic holter; CPAP

\section{ÖZ}

\section{Obstrüktif uyku apne sendromunda PAP tedavisinin enerji metabolizması üzerine etkileri}

Giriş: Bu çalışmada pozitif hava yolu basıncı (PAP) tedavisi uygulanan obstrüktif uyku apne sendromu (OSAS) hastalarında tedavi öncesi ve tedavi sonrası enerji metabolizması değişikliklerini değerlendirmeyi amaçladık.

Materyal ve Metod: Çalışmaya 39 hasta (22 erkek, 17 kadın) kabul edildi. Polisomnografi (PSG)'de orta-ă̆ır OSAS saptanıp PAP tedavisi planlanan hastalar dahil edildi. PAP tedavisi öncesi ve sonrasında üç gün boyunca metabolik holter cihazı (SenseWear Pro3 Armband, SWA) ile enerji metabolizması değerleri kaydedildi.

Bulgular: Hastaların yaş ortalaması $51.53 \pm 11.16$ yıl idi. Hastaların 15 (\%38.46)'ine BPAP, 24 (\%61.54)'üne CPAP tedavisi başlandı. Üç gün metabolik holter cihazı kullanımı sonrasında; hastaların günlük toplam enerji tüketimi, tedavi öncesinde $482.44 \pm 296$ kcal/gün, tedavi sonrasında $524.51 \pm 343.18$ kcal/gün olup, tedavi sonrasında istatiksel olarak anlamlı yüksek idi ( $p<0.0001)$; hastaların günlük fiziksel aktivitesi (günlük yürüyüş mesafesi, toplam adım sayısı) tedavi öncesinde $7867 \pm 3319$ adım/gün, tedavi sonrasında $12.416 \pm 1451$ adım/gün olup, tedavi sonrasında istatistiksel olarak anlamlı yüksek idi ( $p<0001)$; hastaların günlük toplam istirahat süresi (immobilizasyon, uyku dahil toplam uzanma süresi) tedavi öncesinde $7.90 \pm 1.36$ saat/gün, tedavi sonrasında $7.44 \pm$ 1.42 saat/gün olup tedavi sonrasında istatistiksel olarak anlamlı düşük idi ( $p<0001)$; hastaların günlük toplam uyku süresi tedavi öncesinde $5.50 \pm 1.88$ saat/gün, tedavi sonrasında $5.87 \pm 1.20$ saat/gün olup, tedavi sonrasında istatistiksel olarak anlamlı yüksek idi $(p<0001)$.

Sonuç: Çalışmamızda PAP tedavisi ile günlük fiziksel aktivitenin ve enerji tüketiminin artı̆̆̆ını saptadık. PAP tedavisi sayesinde OSAS'a eşlik eden obezite, diyabet, hipertansiyon gibi hastalıklar kontrol altına alınabilir. Çalışmamızda ayrıca PAP tedavisi ile efektif uyku sağlandığından immobilizasyon süresi azalmış ve dolayısıyla gün içi fiziksel aktivite süresi uzamıştır. Bu etkiler sayesinde hastaların tedaviye uyumu artmaktadır. Sonuç olarak, orta ve ağır OSAS'ı hastalarda PAP tedavisi tavsiye edilmelidir.

Anahtar kelimeler: Obstrüktif uyku apne sendromu; enerji metabolizması; fiziksel aktivite; uyku süresi; metabolik holter cihazı; CPAP

\section{INTRODUCTION}

Obstructive Sleep Apnea Syndrome (OSAS) is a sleep respiratory disturbance and it has caracterized by repeted cessations of breathing and airway collaps during sleep. Consequences of OSAS include excessive daytime sleepiness, divided sleep architecture, impaired neurocognitive performance, and psychosocial disruption $(1,2)$. Patients with OSAS have increased morbidity from cardiovascular events and work accidents $(1,3,4)$. The treatment modalities for OSAS are nasal positive airway pressure (PAP) and surgery for some certain conditions. PAP has been shown to reduce daytime sleepiness, oxyhemoglobin desaturations, heart rate, pulmonary pressure, improve cognitive performance, and increase quality of life $(1,5)$.

PAP treatment is the first choice of treatment modality for most OSAS patients. Under PAP device obstructive apnea-hypopneas and snoring recover, heartbeats and $\mathrm{SaO}_{2}$ return to normal range during sleep. Patients who treated with PAP must be encourage to use PAP device to improve compliance $(6,7)$. In practice, many methods of assesing responce to PAP therapy are not objective. In this study we aimed to evaluate effect of PAP treatment on energy metabolism.

\section{MATERIALS and METHODS}

\section{Patients}

Patients over 18 years of age, moderate and severe OSAS were included in the study. Thirty-nine concecutive patients who applied to Sleep Disorders Center of Inonu University Hospital and met the inclusion criteria were enrolled to this study. All patients had nocturnal snoring, excessive daytime sleepines (ESS), and witnessed apnea. ESS was applied to all patients, and cases with high score (ESS > 10) were accepted into the full-night sleep study (8). After full-night polysomnography, PAP device was prescribed to patients with moderate-to-severe OSAS (AHI > 15) and/or excessive daytime sleepiness (ESS > 10). These indications for PAP treatment were inclusion criteria after three nights (minimum four hours in a night) collected data on Metabolic Holter Device was analyzed. Patients were advised to continue their normal daily life after wearing metabolic holter device. No suggestions for extra exercise have been advised. 


\section{Polysomnography}

Full-night polysomnography was performed using conventional instrumentation and analysis according to the recommendations on syndrome definition and measurement tecniques published by the American Sleep Medicine. Sleep stages were detailed by standard electroencephalographic, electro-oculographic, and electromyographic criteria. Apneas and hypopneas were recorded by oronasal flow cannulae attached to a pneumotachograph. Arterial oxygen saturation was measured by pulse oximetry using inductive plethsmography to document respiratory effort. Periodical $>3 \%$ limb movements were recorded from surface EMG electrode on tibialis anterior muscle of the lover extremity. Obstructive apneas were defined as absence of airflow for longer than $10 \mathrm{~s}$; obstructive hypopneas as a $50 \%$ decrease in airflow or a clear but lesser decrease in airflow if coupled with either a desaturation of $3 \%$ or an arousal in the context of ongoing respiratory effort. All records were scored manually for sleep stage, arousols, apneas and hypopneas.

\section{Metabolic Holter Device}

Metabolic Holter Device (SWA, SenseWear ${ }^{\circledR}$ ) arm band is a multi-sensor body monitor that can collect continuous lifestyle data for up to two weeks. It is attached to right arm's triceps and calculates energy consumption and metabolic physical activity in the free lifetime environment $(9,10)$. Energy consumption and physical activity, sleep duration and quality can be objectively evaluated with this device $(10,11)$. Physiological variables of the body such as total energy consumption, effective energy consumption, resting energy consumption, Metabolic Equivalency Unit (MET, $\mathrm{kcal} / \mathrm{kg} / \mathrm{h}$ ), total number of steps, duration of physical activity, sleep duration are measured. Physiological body signals from four sensors (skin temperature, heat flow, galvanic skin response and biaxial accelerometer) combined with "theme recognition" templates and by comparing crosswise the physiological body signals that device collected, measures energy consumption accurately.

The SenseWear ${ }^{\circledR}$ arm band accurately measures energy consumption by cross-comparing all the physiological body signals it collects to define the wearer's theme. The level of physical activity, due to the close relationship between health and mortality, the amount of physical activity in daily life and violence's correct detection accepted very important. Thus, in recent years there has been an interest in determining the physical activity in everyday life, especially in sedanter populations such as OSAS and COPD. The metabolic holter device, in a study with 27 patients, sleep and wakefulness identified between medium to high precision and sharpness (12).

In our study, average daily data recorded about patients attached with Metabolic Holter Device in their right arm for at least three days. The energy data calculated from here stored in electronic media on the computer. Patients' energy metabolism values before PAP treatment and one week after treatment were compared.

\section{Statistical Analysis}

Wilcoxon test was used for test parameters before and after PAP therapy. All results were come up with result as mean \pm standard deviation. A Pearson correlation analysis was performed to evaluate the relationship between the variables. $p<0.05$ was considered as significant.

We obtained ethical approval from Malatya Clinical Research Ethics Committee. Preliminary information was provided to the candidates regarding the study. During the study, the WHO Declaration of Helsinki rules were followed. Each patient provided written informed consent to participate in this study.

\section{RESULTS}

The avarage age of the patients was $51.5 \pm 11.1$ year (28-72). Twenty-two (56.4\%) male and $17(43.6 \%)$ female patients were participated the study. The mean AHI value of the patients after PSG was detected 52.80 $\pm 25.73 /$ hour. Twenty-four (61.54\%) patients were using CPAP (Continious Positive Airway Pressure) and $15(38.46 \%)$ patients were using BPAP (Bilevel Positive Airway Pressure).

As it can be seen on the below table, after use of metabolic holter device the total daily energy consumption of the patients was considered statistically significant when compared with pre and post-treatment $(482.4 \pm 296.1 \mathrm{kcal} /$ day before treatment and $524.5 \pm 343.1 \mathrm{kcal} /$ day after treatment). The daily physical activity (daily walking distance, total number of steps) of the patients was considered statistically significant when compared before treatment and after treatment $(7867 \pm 3319$ steps/day before treatment and $12.416 \pm 1451$ steps/day after treatment). Patients' total daily resting time (immobilization, total 
Table 1. Patient data before and after use of metabolic holter device

\begin{tabular}{|lccc|}
\hline & Pretreatment & Posttreatment & p \\
\hline Daily energy consumption (kcal/day) & $482.4 \pm 296.1$ & $524.5 \pm 343.1$ & $<0.0001$ \\
Number of daily steps (steps/day) & $7867 \pm 3319$ & $12416 \pm 1451$ & $<0.0001$ \\
Daily resting time (hours/day) & $7.90 \pm 1.36$ & $7.44 \pm 1.42$ & $<0.0001$ \\
Daily total sleeping time (hours/day) & $5.50 \pm 1.88$ & $5.87 \pm 1.20$ & $<0.0001$ \\
\hline
\end{tabular}

relaxation time including sleep) was considered important when compared before treatment and after treatment $(7.90 \pm 1.36$ hours/day before treatment, $7.44 \pm 1.42$ hours/day after treatment). Patients' daily total sleep duration (hours/day) was considered statistically significant when compared before treatment and after treatment $(5.50 \pm 1.88$ hours/day before treatment, $5.87 \pm 1.20$ hours/day after treatment) (Table 1).

\section{DISCUSSION}

The positive effects of PAP therapy on energy metabolism have been shown in our study; energy consumption's increase was detected significant when compared to before treatment period. Physiological sleep has restoreting effect on musculoskeletal system, hemodynamic system, and neurocognitive system (13). Musculoskeletal system is highly related with energy metabolism. The muscle energy metabolism required for exercise depends on the relationship between cardiac output and ventilation function (14). Hypoxia related muscular disfunction in OSAS patients has been reported formerly (15).

OSAS is associated with decreased exercise capacity, measured by percent predicted peak $\mathrm{O}_{2}$. Increasing OSAS severity, as reflected by higher AHI, predicts impaired exercise capacity in a dose-response fashion both before and after adjustment for significant baseline differences. Several potential mechanisms exist by which OSAS may both impair exercise capacity and increase cardiovascular risk. Decreased maximal lactate concentration and delayed lactate elimination have been observed in OSAS subjects during exercise compared to age and BMI matched controls, suggesting impaired glycolytic and oxidative metabolism, respectively (16-18).

There were significantly increased daily steps counts after PAP therapies compare to pretreatment period. This finding contributes to the energy metabolism of PAP therapy, thus increasing energy consumption.
We have though that increased physical activity is associated decreased sleep related complications.

AASM emphasizes the importance of exercise as a nonpharmacological treatment modality of sleep disorders (19). It has been reported during sleep that metabolic abnormalities cause upper airway collapse and that this recurrent upper airway collapse causes sleep interruption and intermittent hypoxia (20). OSAS patients have a lower exercise capacity with a reduced daily physcial activity and abnormal cardiac responce under stress, as compared to healty subjects (21). In a study with cardiopulmonary exercise test, exercise capacities before and after two months of nasal CPAP administration of 20 severe OSAS subjects compared. $\mathrm{MaxVO}_{2}$ (maximal oxygen consumption) was $20.41 \mathrm{~mL} / \mathrm{kg} / \mathrm{min}$ before treatment, and $26.3 \mathrm{~mL} / \mathrm{kg} / \mathrm{min}$ after treatment. This increase in exercise capacity has been attributed to a result of respiratory reserve, sleep structure and improvement in physical activity (22). Özsaraç and friends in a study total of 64 patients with severe OSAS receiving and not receiving CPAP; compare patients with bicycle ergometer and cardiopulmonary exercise capacities after four weeks of CPAP treatment. In the CPAP receiving group, $\mathrm{VE} / \mathrm{VCO}_{2}$ decreased significantly, so this showed that CPAP treatment can prevent a reduction in exercise capacity (23).

Another symptom we show in our study objectively is that the total daily resting time (immobilization, total resting time including sleeping) and the total daily sleeping time after treatment are significantly decreased in OSAS in which PAP treatment is started. This is a symptom supporting increased energy consumption and PAP treatment increases physical activity of patients and the dependence of patients on bed is reduced. Patients with OSAS spend very long periods in bed and tend to sleep in their daily lives. Excessive daytime sleepiness negatively affects the quality of life and brings public safety concerns with it. Norman and colleagues showed that regular exer- 
cise provided significant reductions in ESS scores and improvements in excessive daytime sleepiness and decreased fatigue symptoms (24). In a study comparing CPAP with other treatment modalities in mild-moderate OSAS, it was found that CPAP significantly reduced ESS values (25).

PAP therapy prevents complications of OSAS such as thromboembolism, constipation, osteoporosis, muscular atrophy and depression. We have detected that patients resting time is decreased compare to without PAP also mean of decreasd resting time is increased physical activity and quality life. Increased energy consumption; can be effective in prevention of cardiovascular, endocrine, musculoskeletal system diseases so that provides controlling of diseases such as hypertension, diabetes.

Our study demonstrated that increased physical activity decreased resting time are related energy metabolism. In conclusion, PAP treatment should be recommended in patients with moderate and severe OSAS.

\section{CONFLICT of INTEREST}

No conflict of interest declared by the authors.

\section{AUTHORSHIP CONTRIBUTIONS}

Concept/Design: All of authors.

Analysis/Interpretation: All of authors.

Data Acquisition: All of authors.

Writting: All of authors.

Critical Revision: All of authors.

Final Approval: All of authors.

\section{REFERENCES}

1. Kryger $M H$, Roth $T$, Dement W. Principles and Practice of Sleep Medicine. $4^{\text {th }}$ ed. Amsterdam: Elsevier, 2005:9691121.

2. Masood A, Phillips B. Sleep apnea. Curr Opin Pulm Med 2000;6:479-84.

3. He J, Kryger MH, Zorick FJ, Conway W, Roth T. Mortality and apnea index in obstructive sleep apnea: experience in 385 male patients. Chest 1988;94:9-14.

4. Zhang J, Song Y, Ji Y, Song Y, Cai S, Yu Y, Liu S, Zhang W. Correlation between coronary artery disease and obstructive sleep apnea syndrome and analysis of risk factors. Exp Ther Med 2018;15:4771-6.

5. Kakkar RK, Berry RB. Positive airway pressure treatment for obstructive sleep apnea. Chest 2007;132:1057-72.
6. Aserinsky E, Kleitman N. Regularly occurring periods of eye motility, and concomitant phenomena, during sleep. Neuropsychiatry 2003;4:454-5.

7. Bollig SM. Encouraging CPAP adherence: It is everyone's job. Respiratory Care 2010;55:1230-9.

8. Johns MW. A new method for measuring daytime sleepiness. Sleep 1991;14:540-5.

9. Malavolti $M$, Pietrobelli A, Dugoni $M$, Poli $M$, Romagnoli $E$, De Cristofaro $P$, et al. A new device for measuring daily total energy expenditure (TEE) in free living individuals. International Journal of Body Composition Research 2005;3:63.

10. Patel SA, Slivka WA, Sciurba FC. Validation of a wearable body monitoring device in COPD. Am J Respir Crit Care Med 2004;30:771.

11. Mignault $D$, Onge $M$, Karelis $A D$. Evaluation of the Portable HealthWear Armband, a device to measure total daily energy expenditure in free living type 2 diabetic individuals. Diabetes Care 2005;28:225-7.

12. Germain A, Buysse DJ, Nofzinger E. Sleep-specific mechanisms underlying posttraumatic stress disorder: integrative review and neurobiological hypotheses. Sleep Med Rev 2008; 12:185-95.

13. Van Dongen HP, Maislin G, Mullington JM, Dinges DF. The cumulative cost of additional wakefulness: dose-response effects on neurobehavioral functions and sleep physiology from chronic sleep restriction and total sleep deprivation. Sleep 2003;26:117-26.

14. Wasserman K, Whipp BJ. Exercise physiology in health and disease. Am Rev Respir Dis 1975;112:219-49.

15. Eriksson $\mathrm{LI}$, Wictorsson $\mathrm{Y}$, Henriksson KG. Post-traumatic glycogen depletion in type I and type II muscle fibers in man. Clin Nutrition 1988;7:49-52.

16. Beitler JR, Awad KM, Bakker JP, Edwards BA, DeYoung P, Djonlagic I, et al. Obstructive sleep apnea Is associated with impaired exercise capacity: a cross-sectional study. J Clin Sleep Med 2014;10:1199-204.

17. Vanuxem D, Badier $M$, Guillot $C$, Delpierre S, Jahjah $F$, Vanuxem P. Impairment of muscle energy metabolism in patients with sleep apnoea syndrome. Respir Med 1997;91:551-7.

18. Sauleda J, García-Palmer FJ, Tarraga S, Maimó A, Palou A, Agustí AG. Skeletal muscle changes in patients with obstructive sleep apnoea syndrome. Respir Med 2003;97:804-10

19. Driver HS, Taylor SR. Exercise and sleep. Sleep Medicine Reviews 2000;4:387-402.

20. Vgontzas AN, Zoumakis E, Bixler EO, Lin HM, Follett $H$, Kales $A$, et al. Adverse effects of modest sleep restriction on sleepiness, performance, and inflammatory cytokines. J Clin Endocrinol Metab 2004;89:2119-26. 
21. Öztürk L, Metin G, Cuhadaroğlu C, Utkusavaş A, Tutluoğ/u $B$. Cardiopulmonary responses to exercise in moderate-tosevere obstructive sleep apnea. Tuberk Toraks 2005;53:108.

22. Ching-Chi Lin CC, Lin CK, Wu KM, Chou CS. Effect of treatment by nasal CPAP on cardiopulmonary exercise test in obstructive sleep apnea syndrome. Lung 2004;182:199212.

23. Ozsarac I, Bayram N, Uyar M, Kosovali D, Gundogdu $N$, Filiz A. Effects of positive airway pressure therapy on exercise parameters in obstructive sleep apnea. Ann Saudi Med 2014;34:302-7.
24. Norman JF, Von Essen SG, Fuchs RH, McElligott $M$. Exercise training effect on obstructive sleep apnea syndrome. Sleep Res 2000;3:121-30.

25. Marshall NS, Barnes M, Travier N, Campbell AJ, Pierce RJ, McEvoy RD, Neill AM, Gander PH. Continuous positive airway pressure reduces daytime sleepiness in mild to moderate obstructive sleep apnea: a meta-analysis. Thorax 2006;61:430-4. 